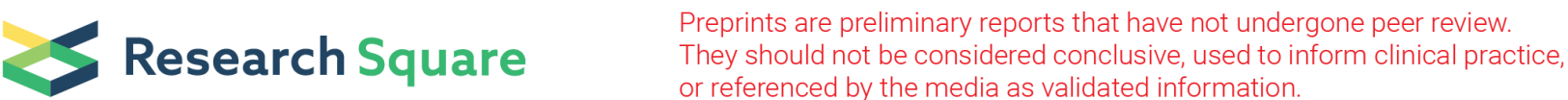

\section{Quantifying Radial Growth Response of Pinus Yunnanensis to Climate Change and Drought Event at Different Altitudes and Ages in the Jinsha River Basin}

Jianrong Su ( $\sim$ jianrongsu@vip.sina.com )

Research Institute of Resources Insect, Chinese Academy of Forestry

Jiayan Shen

Research Institute of Resources Insects, Chinese Academy of Forestry

Shuaifeng Li

Research Institute of Resources Insects, Chinese Academy of Forestry

Xiaobo Huang

Research Institute of Resources Insects, Chinese Academy of Forestry

Wande Liu

Research Institute of Resources Insects, Chinese Academy of Forestry

Xuedong Lang ( $\sim$ langxuedong@gmail.com)

Research Institute of Resources Insects, Chinese Academy of Forestry

\section{Research}

Keywords: Pinus yunnanensis, radial growth, climate change, drought event, resilience, altitudes, ages.

Posted Date: June 23rd, 2021

DOl: https://doi.org/10.21203/rs.3.rs-633818/v1

License: (c) (i) This work is licensed under a Creative Commons Attribution 4.0 International License.

Read Full License 


\section{Abstract \\ Background}

The relative influence of climate change and drought events on tree growth at different altitude and tree ages remains insufficiently understood in the Jinsha River Basin, southwest China, limiting prediction of forest adaptability to high-frequency droughts and climate change. We conducted a dendroecological study to explore and quantify the dominant climate factors that determining radial growth of Pinus yunnanensis trees of different ages and at different altitudes, to evaluate their resilience to drought events.

\section{Results}

Radial growth of $P$. yunnanensis at high elevations is typically limited by low temperatures, the explanatory rate of temperature factors on growth increased from 23.6-59.7\% with altitude. Tree growth at low elevations is more sensitive to moisture factors, the explanatory rate of moisture factors on growth decreased from $76.4-40.3 \%$ with altitude. The young and mature trees are more prone to moisture factors than middle-age and near-mature trees, the young and near-mature trees are more prone to temperature factors than middle-age and mature trees. The older trees usually showed less drought resistance and recovery than the young and middle-age trees. The resistance and recovery of $P$. yunnanensis weakened with the increased frequency of drought events. Tree resistance and resilience was highly dependent on the average pre-drought growth, whereas the recovery showed weak or no significant relationships with average pre-drought growth.

\section{Conclusion}

Our study demonstrates that radial growth of $P$. yunnanensis trees showed age- and altitude-specific demand for energy and moisture. $P$. yunnanensis trees at different altitudes and ages are differentially adapted to varying levels of climate stress and display different strategies to withstand the effects of drought with altitude and ages.

\section{Background}

The consequence of global warming on forest ecosystems are already visible and becoming a major research focus worldwide (Allen et al., 2010; Lévesque et al., 2014). In recent decades, global warming has caused drier conditions and an unexpected increase in the frequency and duration of extreme drought events in many regions of the world (Sterl et al., 2008; Dai et al., 2011a; Vicente-Serrano et al., 2014; Trenberth et al., 2014; Trumbore et al., 2015). The effects of drought stress on forests are likely to be exacerbated by increased temperature and decreased rainfall. Reductions in productivity and widespread increase in tree mortality have happened because of increasing drought (Adams et al., 2017; 
Choat et al., 2018), even in boreal forest where tree growth is not mainly constrained by drought (Peng et al., 2011).

High mountains are deemed to be the most sensitive and vulnerable regions to climate change, which is becoming a matter of global concern (Panthi et al., 2018). Climate change in mountain ecosystems has a critical impact on the growth of trees and the dynamics of high-elevation forests (Liang et al., 2014; Yang et al., 2017). The sensitivity of the altitudinal vertical zone to climate variation is often higher than that of the latitudinal horizontal band (Körner, 2012, 2015) and forests located on mountains are widely considered to be indicators of climate variability (Wang et al., 2015b). In high-mountain regions, altitude affects the radial growth of trees by adjusting water and heat distribution (Fritts, 1976). Temperature and precipitation patterns have spatial variability in the high mountains, a consistent rise in precipitation and decrease in temperature along elevation gradients have been described in many previous studies (Fan et al., 2008a, 2009a; Bhutiyani et al., 2010). Previous studies have indicated that global warming could trigger increased radial growth of trees in temperature-limited high elevations (Fan et al., 2008a, 2009a) by an earlier start of cambial activity (Zhang et al., 2018), and conceivably relieves stress of trees by improving conditions for photosynthesis (Bunn et al., 2005). Tree growth at high elevations is mostly temperature limited, whereas at lower elevations it is more sensitive to variations of precipitation (Liang et al., 2014; Huo et al., 2017; Kharal et al., 2017; Li et al., 2017a).

Growth decline and tree mortality induced by increasing temperature and drought have increased for large areas across the world (Carnicer et al., 2011; Allen et al., 2015; Gazol et al., 2016; Lucía et al., 2020). Droughts have been affecting forests worldwide and are expected to continue as important drivers of forest change (McDowell et al., 2020). Water-limited forests are usually more susceptible to drought than energy-limited (Allen et al., 2015). Widespread tree mortality following droughts is more likely to occur in drought-prone forests, where water shortages induce a reduction in forest productivity and growth (Camarero et al., 2015). The survival ability of trees has been shown to be related to resistance, recovery, and resilience (Lucía et al., 2020; Gessler et al., 2020). The trees living in drought conditions showed higher resilience to extreme drought through eco-physiological adjustments in sustaining growth than to humid conditions (Helman et al., 2017). In high mountain regions, the ecological resilience of trees to extreme drought varies along climatic gradients and the spatial heterogeneity of habitats (Dorman et al., 2013, 2015; Fang and Zhang, 2018). Research on the ecological resilience of trees to drought events at different altitudes is crucial for understanding how forests can resist and recover from drought across different moisture levels and temperature limitations.

The impact of drought on forest structure and function depends on which trees are most adversely affected; mortality of small trees may modify future forest succession, whereas the mortality of large trees causes disproportionate carbon losses and can damage ecosystem functions (Bennett et al., 2015). Understanding forest responses to drought requires elucidation of how tree size, microenvironment, and species traits jointly influence individual-level drought tolerance, which indicates that tree age and size have important effects on tree resilience to drought. Trees of all ages experience changes in their structure and climate sensitivities, but the age-related changes are likely to modulate the complex 
climate-growth relationships (Mclntyre et al., 2015; Merlin et al., 2015; Matusick et al., 2016; Gillerot et al., 2020). Several studies based on tree rings have demonstrated that different levels of sensitivity to drought at different ages (Hadad et al., 2014). In some species, radial growth of adult trees is more sensitive to climate change than that of younger trees, whereas in some species the climate sensitivity diminishes with age. Previous studies have indicated that large trees can suffer disproportionate mortality in response to drought in both temperate and tropical forests, whereas small trees could display better resistance and resilience (Nepstad et al., 2007; Lutz et al., 2009; Merlin et al., 2015; Bennett et al., 2015; Rowland et al., 2015). In the same drought event, larger trees would suffer a more detrimental impact (Bennett et al., 2015). However, a recent physiological model suggests that large trees destined to die following drought may still exhibit high recovery and resilience (Trugman et al., 2018). Thus, we still have a limited understanding of whether large or small trees would suffer more under drought stress, and how drought resilience varies with tree age and size. For this reason, further research is needed to explore the response of tree growth to drought and identify the main functional mechanisms that drive forest resilience.

Jinsha River is an important tributary to the upper reaches of the Yangtze River, where the wet and dry seasons are distinct. The Jinsha River Basin is highly vulnerable to drought disasters because of its special habitat conditions in the background of southwestern drought, and it has been designated as a typical eco-fragile area and key ecological environment construction. As an important ecological barrier in the lower reaches of the Yangtze River, research on the growth response of typical species to climate change and protection of the ecological environment in the Jinsha River Basin has become increasingly important. Pinus yunnanensis is the most important tree species in southwest China and has shown adaptability to withstand drought. Previous studies have mainly focused on the growth response of $P$. yunnanensis to climate change at specific sites and older trees (Shen et al., 2019; Shen et al., 2020), however, there are few studies of the response to climate change and drought at different altitudes and age classes in the Jinsha River Basin.

Therefore, in this study, we examined $P$. yunnanensis in Huize County in the Jinsha River Basin with the aim of exploring the dominant climate factors that determine the radial growth of $P$. yunnanensis and its resilience to drought events along altitude gradients and age classes, taking a dendrochronological approach. Specifically, we aimed to answer the following three research questions: (1) How does the effects of climate variables on radial growth of $P$. yunnanensis vary along altitudes and age classes? (2) How does the magnitude and the temporal changes of tree-level resilience to drought events across altitudes and age classes? (3) What is the relationship between average pre-drought growth (tree-ring width indices) and resistance, recovery and resilience of trees at different altitudes and age classes? The projected increase in frequency and duration of intense droughts in southwest China may increase stress on the growth of $P$. yunnanensis. By investigating tree growth responses across altitudes and age classes to past climate conditions and extreme drought events, the present sensitivity and future responses to climate can be projected, and we can further predict the dynamics and adaptability of the forest at different age levels. 


\section{Material And Methods}

\section{Study area and climate}

The study area is mainly in Huize County northeastern edge of the Yunnan Plateau, the distribution center of $P$. yunnanensis in the Jinsha River Basin $\left(25^{\circ} 48^{\prime} \mathrm{N}, 103^{\circ} 03^{\prime} \mathrm{W}\right.$, and $\left.27^{\circ} 04^{\prime} \mathrm{N}, 103^{\circ} 55^{\prime} \mathrm{W}\right)$. Huize County is located at the junction of Sichuan and Yunnan Provinces, along the Jinsha River. Meteorological records from the Huize station during the period 1953-2016 reveal that the total annual precipitation averaged $795 \mathrm{~mm}, 60 \%$ of which fell in the summer (from June to August), and the mean annual temperature was $12.9^{\circ} \mathrm{C}$ (Fig.1). Pinus yunnanensis is the main dominant species in the study area and is distributed within 1700 to $3000 \mathrm{~m}$ altitude.

\section{Tree-ring sampling and chronology development}

Increment cores were collected in the natural forest of $P$. yunnanensis along elevation gradients from 1800 to $2600 \mathrm{~m}$. At each elevation, at least 60 trees were sampled, and two increment cores per tree were collected at $1.3 \mathrm{~m}$ height with a 5.15 -mm-diameter increment borer. In total, 480 increment cores were extracted from 240 trees at the sample site in January 2020.

We followed standard dendrochronological techniques for sample preparation and chronology development (Cook and Briffa, 1990). The collected cores were air dried and fixed in a wooden trough, polished with 120-, 400-, and 600-gritted sandpaper until the ring boundaries were visible under magnification (Stokes and Smiley, 1996). Tree-ring width was measured at 0.001-mm resolution under a stereomicroscope, which was linked to a LINTAB digital positioning table (LINTAB ${ }^{\text {TM }} 6$, Rinntech, Germany). We precisely identified the year of each annual ring, conducted cross-dating through curve comparison, and determined the quality of the cross-dating with the COFECHA program (Holmes, 1983), then removed the autocorrelation and low frequency signal of tree growth. Measurements from the two cores were averaged for each tree. We calculated the sliding correlation coefficient between sequences (or between sequence and chronology) to test and correct the cross-dating results. Rings that had low correlation with the main sequence and could not be dated were rejected.

Cores that contained pith were used to determine the actual ages of trees. For cores that were close to the pith, the respective trees' ages were estimated by adding 2-7 rings after comparison of their ring patterns with the cores that had pith (Clark and Hallgren, 2004). We estimated the specific age of each tree with this method and selected at least 20 older trees in each altitude to establish the chronology for different altitudes. According to the age classification standard of $P$. yunnanensis natural forest, we classified the trees into the following age classes: AC1 ( $£ 20$ a, 1999-2019); AC2 (21 a $£$ AC2 $£ 30$ a, 1989-2019); AC3 (31 a $£$ AC3 $£ 40$ a, 1979-2019); AC4 (41 a $£$ AC4 $£ 60$ a, 1959-2019). In each age class chronology, tree ring cores were taken at different altitudes to minimize the elevation divergence on age effects (Wu et al., 2013); the elevation range for each age class chronology is shown in Table 1. 
We standardized the raw ring-width a measurement into dimensionless time series of ring-width indices with the negative-exponential curves function or spline function in the ARSTAN program $($ Cook, 1985) to remove the growth trends and the incongruent fluctuation from inhibition and release of interference competition among trees from raw ring-width series while preserving growth variations that are probably related to climate variability (Fritts, 1976). In total, four standard chronologies for different altitudes and four standard chronologies for different ages were established (Fig.S1 and Table 1). We used the standard deviation (SD), mean sensitivity (MS), and first-order autocorrelation (AC1) to assess the statistical quality of the chronologies. SD estimates the variability from the mean of ring-width series; the MS is an indicator of the relative changes in ring-width variance between consecutive years; the AC1 assesses the influence of the previous year on the current year's growth (Fritts, 1976). The expressed population signal (EPS) and signal-to-noise ratio (SNR) were calculated for the common period analysis to evaluate the signal strength of the site chronologies. A level of 0.85 for EPS is considered to indicate a satisfactory quality of a chronology (Wigley et al., 1984).

Table.1 Statistics of $P$. yunnanensis tree-ring width standard chronologies for each altitude and age class

\begin{tabular}{|c|c|c|c|c|c|c|c|c|}
\hline \multirow{2}{*}{$\begin{array}{l}\text { Standard } \\
\text { chronologies }\end{array}$} & \multicolumn{4}{|c|}{ Elevation(m) } & \multicolumn{4}{|c|}{ Age classes } \\
\hline & 1838 & 2010 & 2369 & 2550 & AC1 & AC2 & AC3 & AC4 \\
\hline $\begin{array}{l}\text { Sample } \\
\text { size(trees/radii) }\end{array}$ & $26 / 47$ & $25 / 46$ & $38 / 63$ & $31 / 58$ & $17 / 24$ & $30 / 48$ & $47 / 71$ & $41 / 64$ \\
\hline Chronology span & $\begin{array}{l}1954- \\
2019\end{array}$ & $\begin{array}{l}1968- \\
2019\end{array}$ & $\begin{array}{l}1954- \\
2018\end{array}$ & $\begin{array}{l}1977- \\
2019\end{array}$ & $\begin{array}{l}1999- \\
2019\end{array}$ & $\begin{array}{l}1991- \\
2019\end{array}$ & $\begin{array}{l}1978- \\
2019\end{array}$ & $\begin{array}{l}1968- \\
2019\end{array}$ \\
\hline Mean sensitivity & 0.29 & 0.22 & 0.18 & 0.20 & 0.24 & 0.17 & 0.22 & 0.20 \\
\hline $\begin{array}{l}\text { Variance in first } \\
\text { eigenvector (\%) }\end{array}$ & 37.94 & 29.21 & 44.67 & 37.62 & 43.59 & 29.1 & 41.29 & 29.95 \\
\hline Standard deviation & 0.29 & 0.23 & 0.20 & 0.25 & 0.21 & 0.17 & 0.24 & 0.23 \\
\hline Signal-to-noise ratio & 18.2 & 10.8 & 2.8 & 9.2 & 6.1 & 4.5 & 16.3 & 13.4 \\
\hline $\begin{array}{l}\text { Expressed } \\
\text { population signal }\end{array}$ & 0.95 & 0.92 & 0.86 & 0.90 & 0.86 & 0.86 & 0.94 & 0.93 \\
\hline
\end{tabular}

\section{Evaluation of climate-growth relationships}

The meteorological data were selected from the Huize Weather Station for 1953 to 2016, including the monthly average temperature (Tmp), monthly precipitation (Pre), and the relative humidity (RH) from the China Meteorological Science Data Sharing Service Network (http://data.cma.cn/data/weatherBk.html). The Palmer Drought Severity Index (PDSI) (1901-2017) was extracted from the CRU grids of the Royal Netherlands Meteorological Service website (https://climexp.knmi.nl/start.cgi) with a resolution of $0.5 \times 0.5^{\circ}$. The PDSI data were used to quantitatively describe the degree of drought stress and test for the 
effect of water availability on tree growth. The precipitation in the study area is concentrated from June to October, whereas the precipitation from January to May is low, often leading to drought.

Correspondingly, the PDSI data from January to May were used to characterize the drought events in the study area. The drought years were then classified according to the following PDSI categories: normal $-0.5<$ PDSI $£ 0.5$; initial drought, $-1<$ PDSI $£-0.5$; light drought, $-2<$ PDSI $£-1$; moderate drought, $-3<$ PDSI $£-2$; severe drought, $-4<$ PDSI $£-3$; extreme drought, PDSI $£-4$.

Response correlations between the tree-ring data (STD chronology) of each elevation and age class and monthly climate data over a 17-month period from June of the previous year to October of the current year were determined by using Dendroclim2002 software. Subsequently, growth-climate relationships were computed for six seasons (previous summer, June to August of the previous year; previous autumn, September to November of the previous year; winter, December to February; spring, March to May; summer, June to August; and the growing season, April to August). We used redundancy analysis (RDA) in CANOCO 5.0 software (Braak, 1994) to further verify the relationship of $P$. yunnanensis radial growth at each altitude and age class with climatic factors.

Multiple regression analysis was used to quantify the effects and importance of moisture and energy to radial growth of $P$. yunnanensis at different altitudes and ages. Tree-ring width index at different altitudes and ages were used as the predictive variables and the climate factors were used as the explanatory variables. $\mathrm{Lm}$ function of the $\mathrm{R}$ software was used for multiple regression analysis, and step function was used to optimize the simplified regression model by backward stepwise regression (van der MaatenTheunissen et al., 2015). We standardize data before analysis to ensure the comparability of model parameters. The percentage of the absolute value of the standardized regression coefficient of each explanatory variable in the simplified regression model to the sum of the absolute value of the regression coefficient of all explanatory variables was used as the explanatory rate of the climate factor to the growth of annual rings (Le Bagousse-Pinguet et al., 2019).

We considered that the tree resilience is reflected by the trees' resistance to perturbation and its ability to recover to the original growth conditions. We used the resistance (Rt) and recovery (Rc) to evaluate the resilience of trees at different altitudes and age classes. The three components were calculated for individual trees following the formulas proposed by Lloret et al. (2011) as follows.

$$
\begin{gathered}
\mathrm{Rt}=D_{r} / \text { Pre } D_{r} \\
\mathrm{Rc}=\text { Post } D_{r} / D_{r} \\
\mathrm{Rs}=\text { Post } D_{r} / \text { Pre } D_{r}
\end{gathered}
$$

where Drindicates the ring-width index in the year of drought; PreDrand PostDrindicate the mean ringwidth indices during the 4 years before and after the drought, respectively. Analysis of variance (ANOVA) 
was also used to test whether the resilience of the trees varied among different age classes, altitudes, and drought event years.

Bose et al., (2020) revealed that the impact of drought on tree resilience is dependent on tree growth during the pre-drought period. The relationship between the predictive variables of resistance, recovery, and resilience of trees and the explanatory variable of average pre-drought growth of trees was tested for different altitudes and age classes by using the Im function in R, and linear regressions were applied to fit the variation trend. Figures were produced with the ggplot2 packages in $\mathrm{R}$.

\section{Results}

\section{Climate-growth relationships at different altitudes and ages}

The climate variation characteristics in Huize climate station from 1953 to 2016 are shown in Fig. 2. Temperature significantly increased at a rate of $0.169^{\circ} \mathrm{C} / 10 \mathrm{a}\left(\mathrm{R}^{2}=0.321, p<0.001\right)$, annual total precipitation showed decreasing trend at a rate of $13.26 \mathrm{~mm} / 10 \mathrm{a}$, although not to a significant level $(p>$ 0.05).

The correlation coefficients between chronologies and seasonal climate factors, and the climate factors selected into the simplified regression model and their explanatory rates for the radial growth of $P$. yunnanensis varied with altitudes (Fig.3a and Table S1). Trees living at the altitude of $1838 \mathrm{~m}$ negatively response to temperature in winter, spring, summer and growing season $(p<0.01)$, while at the altitude of $2520 \mathrm{~m}$ trees showed positive correlations with temperature in winter $(p<0.01)$, spring $(p<0.05)$, summer $(p<0.05)$ and growing season $(p<0.01)$. The explanatory rate of temperature on radial growth of $P$. yunnanensis at the altitude of $1838 \mathrm{~m}$ and $2520 \mathrm{~m}$ was $23.6 \%$ and $59.7 \%$, respectively. Trees living at the lower altitude (1838 $\mathrm{m}$ and $2010 \mathrm{~m})$ positively response to precipitation in current spring $(p<0.01)$ and growing season $(p<0.05)$, the explanatory rate of precipitation on growth was $39.6 \%$ and $36.4 \%$, respectively. At the lowest altitude, trees showed significant positive correlations with $\mathrm{RH}$ in all seasons, whereas trees showed significant negative correlations with $\mathrm{RH}$ at the higher altitude $(2369 \mathrm{~m}$ and 2520 $\mathrm{m})$. The explanatory rate of $\mathrm{RH}$ on radial growth at the altitude of $1838 \mathrm{~m}, 2010 \mathrm{~m}, 2369 \mathrm{~m}$, and $2520 \mathrm{~m}$ was $12.2 \%, 23.5 \%, 40.9 \%$, and $31.7 \%$, respectively. Trees showed positive correlations with PDSI at the lowest altitude $(1838 \mathrm{~m})$, whereas showed negative correlations with PDSI at the highest altitude $(2520 \mathrm{~m})$. The explanatory rate of temperature factors on radial growth of $P$. yunnanensis at the altitude of $1838 \mathrm{~m}, 2010 \mathrm{~m}, 2369 \mathrm{~m}$, and $2520 \mathrm{~m}$ was $23.6 \%, 33.3 \%, 39.0 \%$, and $59.7 \%$, respectively; the explanatory rate of moisture factors on radial growth of $P$. yunnanensis at the altitude of $1838 \mathrm{~m}, 2010 \mathrm{~m}$, $2369 \mathrm{~m}$, and $2520 \mathrm{~m}$ was $76.4 \%, 66.7 \%, 61.0 \%$, and $40.3 \%$, respectively.

The correlation coefficients between chronologies and seasonal climate factors, and the climate factors selected into the simplified regression model and their explanatory rates for the radial growth of $P$. yunnanensis varied with ages (Fig.3b and Table S2). Radial growth of AC1 and AC4 age trees exhibited positive correlations with precipitation in past summer $(p<0.05)$, past autumn $(p<0.01)$, and current 
spring $(p<0.01)$. The explanatory rate of precipitation on radial growth of $A C 1, A C 2, A C 3$, and AC4 age class trees was $8.6 \%, 14.7 \%, 34.1 \%$, and $23.5 \%$, respectively. Radial growth of AC1 age class trees showed positive correlations with $\mathrm{RH}$ from past summer to current spring $(p<0.05)$, the AC4 age class trees showed positive correlations with $\mathrm{RH}$ in past summer $(p<0.05)$, past autumn $(p<0.05)$, and current spring $(p<0.01)$. The explanatory rate of $\mathrm{RH}$ on radial growth of $\mathrm{AC} 1, \mathrm{AC} 2$, and $\mathrm{AC} 4$ age trees was $31.7 \%, 63.7 \%$, and $45.8 \%$, respectively. Radial growth of AC4 age trees showed positive correlation with PDSI in past summer $(p<0.05)$, the explanatory rate of PDSI on growth was up to $21.7 \%$. The explanatory rate of temperature factors on radial growth of $P$. yunnanensis of AC1, AC2, AC3, and AC4 age trees was $59.7 \%$, $14.6 \%, 65.9 \%$, and $9.1 \%$, respectively; the explanatory rate of moisture factors on radial growth of $P$. yunnanensis of $A C 1, A C 2, A C 3$, and $A C 4$ was $40.3 \%, 85.4 \%, 34.1 \%$, and $90.9 \%$, respectively.

The RDA of tree radial growth with climate factors at different altitudes and age classes is shown in Fig. 4. Of the 68 climate variables, 7 variables showed significant effects on radial growth of $P$. yunnanensis at different altitudes (Fig. 4a), and 8 variables showed significant effects on radial growth of different age classes (Fig. 4b). Trees living at the lower altitudes (1838 $\mathrm{m}$ and $2010 \mathrm{~m}$ ) significantly positively correlated with precipitation in May of the current year, and the trees living at the altitude of higher altitudes (2369 m and $2520 \mathrm{~m}$ ) significantly positively correlated with temperature in November of the past year. The precipitation in February of the current year (cP2), the PDSI in June of the past (pPDSI6) and current (cPDSI6) year, the RH in October of the past year (pRH10) and in July of the current year (cRH7) showed significantly positive correlations with radial growth of trees at higher altitudes (2369 m and $2520 \mathrm{~m}$ ), whereas showed significantly negative correlations with radial growth at lowest altitude (1838 m). Similarly, the young (AC1), middle-age (AC2), and mature (AC4) trees showed significantly negative correlation with PDSI in May of the current year (CPDSI5), and the near-mature (AC3) trees showed significant positive correlation with temperature in November of the past year (pT11). The precipitation in August (pP8) of the past year, the RH in October of the past year (pRH10) and in May of the current year (CRH5) showed significantly positive correlations with young (AC1), middle-age (AC2), and mature (AC4) trees, whereas showed significantly negative correlation with near-mature (AC4) trees.

\section{Radial growth response of $P$. yunnanensis to drought}

We defined the drought events based on the PDSI during January to May. The four strongest drought events were identified as occurring in 2010, 2012, 2013, and 2014, and were used in the analysis of tree resilience to droughts. Among these, 2012 was defined as a moderate drought year, whereas 2010, 2013, and 2014 were defined as the severe drought years (Fig. 5).

The Rt, Rc, and Rs of $P$. yunnanensis to drought varied among different altitudes (Fig. 6a) (Table S3; Table S4) and age classes (Fig. 6b) (Table S3; Table S5). The Rt of trees at lower altitudes was stronger than that at higher altitudes in the 2010 and 2014 drought events, and the Rc of trees at the lower altitudes were stronger than that at the higher altitudes in 2012 and 2013 drought events; the Rs of trees at low altitude $(1838 \mathrm{~m})$ was significantly stronger than that at higher altitudes $(2010,2369$, and $2520 \mathrm{~m})$, the Rs significantly decreased with altitudes $(p<0.001)$ in the 2013 and 2014 drought events. 
The Rt of trees enhanced with age except the AC4 age class in 2012 drought events, whereas it decreased with age except the AC4 age class in the 2014 drought event. The Rc was strongest for AC1 age class trees and weakest for AC3 age class trees. The Rs for the AC3 age class trees was lower than those of other age classes during the 2013 and 2014 drought events.

\section{Temporal change in tree growth resilience to drought}

We evaluated the temporal change in resilience of all sampled trees (Fig.7). The results revealed that the $\mathrm{Rt}, \mathrm{Rc}$, and Rs of the sampled trees varied significantly in different drought events $(p<0.001)$. The Rt of the trees increased significantly from 2010 to 2013 drought events, whereas decreased significantly in 2014 drought event; the Rc showed decreasing trend from 2010 to 2013 drought event, whereas increased in 2014 drought event, and the variation trend is opposite to that of Rt; the Rs of trees in 2014 drought event significantly enhanced than 2010 and 2012 drought events.

We analyzed the relationship between Rc and Rt of trees in the different altitudes and age classes (Fig. 8). The results revealed that the Rc and Rt of trees showed significant $(p<0.05)$ negative relationships in each altitude and age class.

\section{Correlations of resistance, recovery and resilience with average pre-drought growth of trees}

We tested the relationships of Rt, Rc, and Rs of $P$. yunnanensis with the average pre-drought growth at different altitudes and age classes (Fig. 9). The Rt of trees was significant negatively correlated with average pre-drought growth $(p<0.01)$. The relationship between Rt and average pre-drought growth at the higher altitudes was stronger than those at lower altitudes. Similarly, the Rt of the AC3 (Slope $=-0.710, p$ $<0.0001$ ) and AC4 age class trees (Slope $=-0.702, p<0.0001$ ) showed stronger relationships with average pre-drought growth than the $\mathrm{AC} 2$ and $\mathrm{AC} 1$ age class trees.

The Rc of trees was negatively associated with average pre-drought growth and varied significantly across the four altitudes and age classes. The Rc of trees at the altitudes of $2010 \mathrm{~m}$ (Slope $=-0.186, p<$ $0.001)$ and $2369 \mathrm{~m}$ (Slope $=-0.548, p<0.05$ ) showed significant negative correlations with average-predrought growth, whereas the trees at $1838 \mathrm{~m}$ and $2520 \mathrm{~m}$ altitude showed no significant correlations $(p>$ $0.05)$ with average pre-drought growth. The Rc of the AC1 $(p<0.01), \operatorname{AC2}(p<0.001)$, and AC4 $(p<0.01)$ age class trees showed significant correlations with average pre-drought growth, whereas the AC3 age class trees showed no significant correlation $(p>0.05)$.

The Rs was negatively significantly correlated with average pre-drought growth for all altitudes and age classes $(p<0.001)$. The relationship between Rs and average pre-drought growth at the highest altitude $2520 \mathrm{~m}$ (Slope $=-0.356, p<0.001)$ was weaker than at the lower altitudes $(1838 \mathrm{~m}, 2010 \mathrm{~m}, 2369 \mathrm{~m})$. The Rs of the AC1 age class trees showed the strongest relationship with average pre-drought growth (Slope $=-2.410, p<0.0001)$.

\section{Discussion}




\section{Radial growth response of $P$. yunnanensis to climate at different altitudes and age classes}

The results of climate response analysis and redundancy analysis (RDA) are consistent (Fig. 3a and Fig. 4a). Trees living at the lower altitude (1838 $\mathrm{m}$ and $2010 \mathrm{~m}$ ) positively response to moisture factors (precipitation, relative humidity, and PDSI), while at the higher altitude (2369 m and $2520 \mathrm{~m}$ ), the opposite is true. The explanatory rate of temperature factors on radial growth of $P$. yunnanensis increased from $23.6 \%$ to $59.7 \%$ with altitude, while the explanatory rate of moisture factors on radial growth decreased from $76.4 \%$ to $40.3 \%$ with altitude. Our results support the findings of previous studies that radial tree growth at high elevations is typically limited by low temperatures, whereas tree growth at low elevations is more sensitive to precipitation and water availability (Babst et al., 2013; Panthi et al., 2018). Compared with the higher elevations, drought stress due to less precipitation and higher temperature at lower elevations leads to enhanced sensibility of radial growth to moisture availability, especially in the pregrowing season and early growing season (Hartl-Meier et al., 2014a), the explanatory rate of moisture factors during pre-growing season and early growing season on radial growth of trees was up to $31.2 \%$. Trees present at the highest elevation $(2520 \mathrm{~m})$ were more sensitive to lower temperature and higher water availability. Summer temperature was found to be the most important factor determining the radial growth of trees present at the highest altitude $(2520 \mathrm{~m})$, the explanatory rate of summer temperature on radial growth was up to $26.6 \%$. The results support the hypothesis that tree radial growth benefits from elevated growing season temperature, and consistent with the findings of previous studies conducted on other high mountains (Lyu et al., 2017; Panthi et al., 2018). Elevated summer temperatures may induce higher rates of cambial growth and xylem cell production (Rossi et al., 2014). Water availability at high altitudes showed negative effects on the radial growth of trees, which had adverse effects on tree growth compared with lower elevations. The result is attributed to the higher cloud cover and frequency of foggy conditions at high altitudes, which reduces the solar radiation input and photosynthetic active radiation by decreasing the total sunshine duration (Jiao et al., 2016).

Our results reveal that the sensitivity of the radial-growth response to seasonal climate factors of $P$. yunnanensis varied with altitude and age. The young and mature trees showed stronger positive sensitivity to precipitation than middle-age and near-mature trees (Fig. 3b and Fig. 4b), indicating variations in climate sensitivity of growth according to age category. The explanatory rate of moisture factors on radial growth of middle-age and mature trees was up to $85.4 \%$ and $90.9 \%$, respectively. Furthermore, the explanatory rate of relative humidity and precipitation on radial growth of older trees was higher than younger trees, which indicated that the older trees are more prone to moisture factors in drought events. Compared with younger trees, older trees usually have a higher hydraulic resistance with a corresponding reduced efficiency of water transport, which could contribute to the slowing of tree growth as their size increases (Ryan et al., 1997). The explanatory rate of temperature factors on radial growth of young and near-mature trees was up to $59.7 \%$ and $65.9 \%$, respectively. The differences in climate sensitivity between age classes are usually attributed to different levels of competition for light, water, and other resources (Linares et al., 2009, 2010). Our results support the previous finding that both growth and the growth response to abiotic factors may potentially vary as trees age (Bond et al., 2007). The hydraulic limitations can partially explain the variations of climate sensitivity of different aged trees 
(Carrer and Urbinati, 2004; Yu et al., 2008). The variable climate sensitivity of trees of different ages implies that they are differentially adapted to varying levels of climatic stress (Galván et al., 2014). Our research further revealed that the inclusion of young and mature trees in the construction of tree-ring chronologies could increase the resolution of the climatic signals of tree rings (Hadad et al., 2014).

\section{The resistance, recovery and resilience of trees to drought}

Our results support our hypothesis that drought sensitivity varies among trees at different altitudes and among age groups, indicating that trees display different strategies among these categories to withstand the effects of drought (Bose et al., 2020). The results further support previous conclusions that the ecological resilience of trees to extreme drought varies along climatic gradients and the spatial heterogeneity of habitats (Gazol et al., 2016; Sánchez-Salguero et al., 2018). Drought resistance of trees decreased with altitude in the 2010 and 2014 drought events, whereas drought recovery increased. In the 2012 and 2013 drought events, tree resistance of high altitudes was stronger than that at lower altitudes, whereas recovery showed the opposite trend. The results of temporal variation (Fig. 7) showed that the $\mathrm{Rt}, \mathrm{Rc}$, and Rs of $P$. yunnanensis features a regular variation with drought frequency and conditions rather than remaining unchanged. This pattern suggests the increased frequency of drought would weaken the resistance and recovery of trees, the vulnerability of trees to drought increased after the successive drought episodes (Serra-Maluquer et al., 2018; Bose et al., 2020). Subsequent droughts generally have a more deleterious impact than initial droughts, the increased drought frequency and duration could result in "cumulative effects" and persistent physiological damage, and further decrease tree resilience to subsequent droughts (Hacke et al., 2001; Sala et al., 2012). The variation trend of Rc is opposite to that of Rt, the combination with the results of correlations between Rt and Rc (Fig. 8) further suggest a trade-off between growth resistance and recovery to drought (Gazol et al., 2016; Bose et al., 2020); trees with stronger growth reductions (low resistance) during drought are indeed capable of recovering faster than trees with higher resistance. The majority of resistance values were located within a narrow band (roughly 0.3 to 1.5 ), whereas there was a much wider range of recovery values (roughly 0.5 to 4.5 ). The narrow band of resistance values seems surprising when considering that trees living at different altitudes and age classes should operate across a large range because of their varied water use strategies. However, the much larger variability of recovery values compared with resistance indicates that recovery of $P$. yunnanensis may be more plastic than that of resistance (Schwarz et al., 2020).

Our results showed a significant effect of tree age on Rt, Rc, and Rs. Nevertheless, this effect was relatively weak and was not consistent among all drought events. The Rt of trees enhanced with age (except for the mature trees) in the 2010 and 2012 drought events, whereas it decreased with age (except for the mature trees) in the 2014 drought event. These results were consistent with many previous studies that the tree size and age showed a positive relation with vulnerability to drought, with the larger and older trees usually showing the least resistance and recovery from drought (Bennett et al., 2015; Rowland et al., 2015; Matusick et al., 2016; Serra-Maluquer et al., 2018). The growth and mortality rates of larger trees have been shown to change unfavorably with drought (Bennett et al., 2015; McGregor et al., 2020). In contrast to the larger trees, young trees face less unfavorable conditions during drought. The position 
of larger trees in the stand and their inherent physiological constraints (elevated atmospheric water demands and longer hydraulic path lengths) determine that they may face more stress during drought than young trees (Ryan et al., 2006; McDowell et al., 2015). The more pronounced drought sensitivity of larger trees could be underpinned by their greater inherent vulnerability to hydraulic stress (Zhang et al., 2009; McDowell et al., 2015). The Rc was strongest for young trees and weakest for near-mature trees, and the near-mature trees also showed the lowest Rs in 2013 and 2014 drought events. Trees attempt to repair water transport tissue through regrowing drought-damaged xylem after drought, however the number of years of xylem regrowth required to recover function increases with tree size (Gaylord et al., 2015; Trugman et al., 2018), which explaining why the younger trees showed more stronger recovery than the older.

\section{Correlations between average pre-drought growth and resilience of trees}

The average pre-drought growth significantly affected the Rt and Rs of trees at all altitudes and age classes. Average pre-drought growth showed a stronger negative relationship with $\mathrm{Rt}$ in trees at the higher altitudes than those at lower altitudes. This result reveals that the impact of drought on tree-level resilience is not independent, but rather is dependent on how the trees were growing during the predrought period and the environment they were growing within (Bose et al., 2020). Our finding of higher average pre-drought growth being associated with decreased resistance to drought events confirms the findings of previous studies, which have frequently identified higher drought tolerance in trees to be associated with lower relative growth rates (Taeger et al., 2013; Zang et al., 2014). Higher aboveground biomass growth would reduce the biomass allocation to roots and consequently increase tree-level sensitivity to upcoming drought periods (Gessler et al., 2017). A smaller aboveground growth could be related to an increase of root to shoot allocation ratio, which could improve water uptake later. Our results are consistent with those of Serra-Maluquer et al. (2018), which revealed that trees growing under more favorable conditions (more humid climates) and thus showing higher growth rates may be less resistant and resilient to drought. The average pre-drought growth showed weak or no significant relationships with the recovery of trees (Fig. 9). Recovery of trees might highly depend on the annual growth in years with extreme drought effects and post-drought growth. Tree resistance is more easily affected by average pre-drought growth in older trees than in younger trees.

\section{Conclusion}

In this study, we combined meteorological and dendrological methods to quantify the dominant climate factors that determining radial growth of $P$. yunnanensis trees of different ages and at different altitudes, and further evaluate their resilience to extreme drought event. Our results reveals that the climate sensitivity of $P$. yunnanensis vary as trees age, and they are differentially adapted to varying levels of climate stress, the older trees are more prone to moisture factors, the young and near-mature trees are more prone to temperature factors. Effects of temperature factors on radial growth of $P$. yunnanensis enhanced with altitude, and effects of moisture factors on radial growth of $P$. yunnanensis weakened with altitude. P. yunnanensis of different ages growing at different altitudes display different strategies to 
withstand the effects of drought. The age- and altitude-specific response of $P$. yunnanensis to drought stress provides useful information to understand the age- and altitude-related variation of tree demand for energy and moisture, which may help to understand the adaptive strategies and ecological thresholds of $P$. yunnanensis. The Rt and Rs of $P$. yunnanensis to drought events are highly dependent on the average pre-drought growth, tree age, and altitude. As a next step, the Rs of trees should be researched across different species, forest systems, and drought stress levels. Our results provide useful information to understand how climate, environment, biology, and other comprehensive factors influence the ecological resilience of trees to drought events, which may help to evaluate the future health of trees and the sustainable development of forests in the Jinsha River Basin.

\section{Declarations}

\section{Ethics approval and consent to participate}

Not applicable.

\section{Consent for publication}

Not applicable.

\section{Availability of data and materials}

The datasets analyzed during the current study are available from the corresponding author on reasonable request.

\section{Competing interests}

The authors declare that they have no competing interests.

\section{Funding}

This manuscript was funded by the Fundamental Research Funds of CAF (CAFYBB2017ZX002) and Yunnan Basic Research Program (2019FB058).

\section{Authors' contributions}

Jiayan Shen, Shuaifeng Li, Xiaobo Huang, Wande Liu and Xuedong Lang conducted the field measurements. Jianrong Su conceived the study and revised the manuscript. Jiayan Shen drafted the manuscript.

\section{Acknowledgements}

We would like to thank LetPub (www.letpub.com) for its linguistic assistance and grammatical editing during the preparation of this manuscript. 


\section{References}

1. Allen C, Macalady A, Chenchouni H, Bachelet D, McDowell N, Vennetier M, Kitzberger T, Rigling A, Breshears D, Hogg E, Gonzalez P, Fensham R, Zhang Z, Castro J, Demidova N, Lim J, Allard G, Running S, Semerci A, Cobb N (2010) A global overview of drought and heat-induced tree mortality reveals emerging climate change risks for forests. Forest Ecology and Management 259(4):660-684. https://doi:10.1016/j.foreco.2009.09.001

2. Allen C, Breshears D, McDowell N (2015) On underestimation of global vulnerability to tree mortality and forest die-off from hotter drought in the Anthropocene. Ecosphere 6(8): art129. https://doi:10.1890/ES15-00203.1

3. Anderegg W, Schwalm C, Biondi F, Camarero J, Koch G, Litvak M, Ogle K, Shaw D, Shevliakova E, Williams A, Wolf A, Ziaco E, Pacala S (2015) Pervasive drought legacies in forest ecosystems and their implications for carbon cycle models. Science 349(6247):528-532. https://doi:10.1126/science.aab1833

4. Babst F, Poulter B, Trouet V, Tan K, Neuwirth B, Wilson R, Carrer M, Grabner M, Tegel W, Levanic T, Panayotov M, Urbinati C, Bouriaud O, Ciais P, Frank D (2013) Site-and species-specific responses of forest growth to climate across the European continent. Global Ecology and Biogeography 22(6):706717. https://doi:10.1111/geb.12023

5. Bennett A, McDowell N, Allen C, Anderson-Teixeira K (2015) Larger trees suffer most during drought in forests worldwide. Nature Plants 1(10):15139-15144. https://doi:10.1038/nplants.2015.139

6. Bhutiyani M, Kale V, Pawar N (2010) Climate change and the precipitation variations in the northwestern Himalaya: 1866-2006. International Journal of Climatology 30(4):535-548. https://doi:10.1002/joc.1920

7. Bond B, Czarnomski N, Cooper C, Day M, Greenwood M (2007) Developmental decline in height growth in Douglas-fir. Tree Physiology 27(3):441-453. https://doi:10.1093/treephys/27.3.441

8. Bose A, Gessler A, Bolte A, Bottero A, Buras A, Cailleret M, Camarero J, Haeni M, Hereş A, Hevia A, Lévesque M, Linares J, Martinez-Vilalta J, Matías L, Menzel A, Sánchez-Salguero R, Saurer M, Vennetier M, Ziche D, Rigling A (2020) Growth and resilience responses of Scots pine to extreme droughts across Europe depend on pre-drought growth conditions. Global Change Biology 26:45214537. https://doi:10.1111/gcb.15153

9. Braak C (1994) Canonical community ordination. I. Basic theory and linear methods. Ecoscience 1: 127-140. https://doi.org/10.1080/11956860.1994.11682237

10. Bunn A, Graumlich L, Urban D (2005) Trends in twentieth-century tree growth at high elevations in the Sierra Nevada and White Mountains, USA. The Holocene 15(4):481488. https://doi:10.1191/0959683605hl827rp

11. Camarero J, Gazol A, Tardif J, Conciatori F (2015) Attributing forest responses to global-change drivers: Limited evidence of a CO2-fertilization effect in Iberian pine growth. Journal of Biogeography 42(11):2220-2233. https://doi:10.1111/jbi.12590 
12. Carnicer J, Coll M, Ninyerola M, Pons X, Sanchez G, Penuelas J (2011) Widespread crown condition decline, food web disruption, and amplified tree mortality with increased climate change-type drought. Proceedings of the National Academy of Sciences 108(4):1474-

1478. ttps://doi:10.1073/pnas.1010070108

13. Carrer M, Urbinati C (2004) Age-dependent tree-ring growth responses to climate in Larix decidua and Pinus cembra. Ecology 85(3):730-740. https://doi:10.1890/02-0478

14. Clark SL, Hallgren, SW (2004) Age estimation of Quercus marilandica and Quercus stellata: applications for interpreting stand dynamics. Canadian Journal of Forest Research 34(6):13531358. https://doi:10.1139/x04-020

15. Cook E, Briffa K (1990) Tree-ring standardization and growth-trend estimation. Methods of Dendrochronology: Application in Environmental Science. Kluwer Academic Press, Netherlands.

16. Dai A (2011) Drought under global warming: a review. Wiley Interdisciplinary Reviews: Climate Change 2(1):45-65. https://doi:10.1002/wcc.81

17. Dorman M, Svoray T, Perevolotsky A, Sarris D (2013) Forest performance during two consecutive drought periods: Diverging long-term trends and short-term responses along a climatic gradient. Forest Ecology and Management 310: 1-9. https://doi:10.1016/j.foreco.2013.08.009

18. Dorman M, Perevolotsky A, Sarris D, Svoray T (2015) The effect of rainfall and competition intensity on forest response to drought: lessons learned from a dry extreme. Oecologia 177(4): 10251038. https://doi:10.1007/s00442-015-3229-2

19. Fan Z, Bräuning A, Cao K (2008) Annual temperature reconstruction in the central Hengduan Mountains, China, as deduced from tree rings. Dendrochronologia 26(2):97107. https://doi:10.1016/j.dendro.2008.01.003

20. Fan Z, Bräuning A, Cao K, Zhu S (2009a) Growth-climate responses of high-elevation conifers in the central Hengduan Mountains, southwestern China. Forest Ecology and Management 258(3):306313. https://doi:10.1016/j.foreco.2009.04.017

21. Fang OY, Zhang QB (2018) Tree resilience to drought increases in the Tibetan Plateau. Global Change Biology 25:245-253. https://doi:10.1111/gcb.14470

22. Fritts H (1976) Tree Rings and Climate. Elsevier, New York. https://doi:10.1038/scientificamerican0572-92

23. Galván J, Camarero J, Gutiérrez E, Zuidema P (2014) Seeing the trees for the forest: drivers of individual growth responses to climate in Pinus uncinata mountain forests. Journal of Ecology 102(5):1244-1257. https://doi:10.1111/1365-2745.12268

24. Gaylord ML, Kolb TE, McDowell NG (2015) Mechanisms of pinon pine mortality after severe drought: a retrospective study of mature trees. Tree Physiology 35(8):806816. https://doi:10.1093/treephys/tpv038

25. Gazol A, Camarero J, Anderegg W, Vicente-Serrano S (2016) Impacts of droughts on the growth resilience of Northern Hemisphere forests. Global Ecology and Biogeography 26(2):166176. https://doi:10.1111/geb.12526 
26. Gessler A, Schaub M, McDowell N (2016) The role of nutrients in drought-induced tree mortality and recovery. New Phytologist 214(2):513-520. https://doi:10.1111/nph.14340

27. Gessler A, Bottero A, Marshall J, Arend M (2020). The way back: recovery of trees from drought and its implication for acclimation. New Phytologist 228:1704-1709. https://doi:10.1111/nph.16703

28. Gillerot L, Forrester D, Bottero A, Rigling A, Lévesque M (2020) Tree Neighbourhood Diversity Has Negligible Effects on Drought Resilience of European Beech, Silver Fir and Norway Spruce. Ecosystems 24:20-36. https://doi:10.1007/s10021-020-00501-y

29. Hadad M, Roig J, Boninsegna J, Patón D (2014) Age effects on the climatic signal in Araucaria araucana from xeric sites in Patagonia, Argentina. Plant Ecology and Diversity 8(3):343-351. https://doi:10.1080/17550874.2014.980350

30. Hacke U, Stiller V, Sperry J, Pittermann J, McCulloh K (2001) Cavitation fatigue. Embolism and refilling cycles can weaken the cavitation resistance of xylem. Plant Physiology 125(2):779786. https://doi:10.2307/4279703

31. Hartl-Meier C, Dittmar C, Zang C, Rothe A (2014a) Mountain forest growth response to climate change in the Northern Limestone Alps. Trees 28(3):819-829. https://doi:10.1007/s00468-014-09941

32. Helman D, Lensky I, Yakir D, Osem Y (2016) Forests growing under dry conditions have higher hydrological resilience to drought than do more humid forests. Global Change Biology 23(7): 28012817. https://doi:10.1111/gcb.13551

33. Holmes R (1983) Computer-assisted quality control in tree-ring dating and measurement. Tree-Ring Bull 43:69-95. https://doi:10.1006/biol.1999.0214

34. Huo Y, Gou X, Liu W, Li J, Zhang F, Fang K (2017) Climate-growth relationships of Schrenk spruce (Picea schrenkiana) along an altitudinal gradient in the western Tianshan Mountains, northwest China. Trees 31(2):429-439. https://doi:10.1007/s00468-017-1524-8

35. Jiao L, Jiang $Y$, Wang $M$, Kang $X$, Zhang W, Zhang L, Zhao S (2016) Responses to climate change in radial growth of Picea schrenkiana along elevations of the eastern Tianshan Mountains, northwest China. Dendrochronologia 40:117-127. https://doi:10.1016/j.dendro.2016.09.002

36. Kharal D, Thapa U, George S, Meilby H, Rayamajhi S, Bhuju D (2016) Tree-climate relations along an elevational transect in Manang Valley, central Nepal. Dendrochronologia 41:57-64. https://doi:10.1016/j.dendro.2016.04.004

37. Melanie S (2013) Alpine Treelines: Functional Ecology of the Global High Elevation Tree Limits. Mountain Research and Development 33(3):357-357. https://doi:10.1659/mrd.mm124

38. Körner C (2015) Paradigm shift in plant growth control. Current Opinion in Plant Biology 25:107-114. https://doi:10.1016/j.pbi.2015.05.003

39. Lévesque $M$, Rigling A, Bugmann $H$, Weber P, Brang P (2014) Growth response of five co-occurring conifers to drought across a wide climatic gradient in Central Europe. Agricultural and Forest Meteorology 197:1-12. https://doi:10.1016/j.agrformet.2014.06.001 
40. Liang E, Dawadi B, Pederson N, Eckstein D (2014) Is the growth of birch at the upper timberline in the Himalayas limited by moisture or by temperature? Ecology 95(9):2453-2465. https://doi:10.1890/131904.1

41. Li JB, Shi JF, Zhang DD, Yang B, Fang KY, Yue PH (2017) Moisture increase in response to highaltitude warming evidenced by tree-rings on the southeastern Tibetan Plateau. Climate Dynamics 48(1-2):649-660. https://doi:10.1007/s00382-016-3101-z

42. Linares JC, Camarero JJ, Carreira JA (2009) Plastic responses of Abies pinsapo xylogenesis to drought and competition. Tree Physiology 29(12):1525-1536. https://doi:10.1093/treephys/tpp084

43. Linares JC, Camarero JJ, Carreira JA (2010) Competition modulates the adaptation capacity of forests to climatic stress: insights from recent growth decline and death in relict stands of the Mediterranean fir Abies pinsapo. Journal of Ecology 98(3):592-603. https://doi:10.1111/j.13652745.2010.01645.x

44. Lloret F, Keeling EG, Sala A (2011) Components of tree resilience: Effects of successive low-growth episodes in old ponderosa pine forests. Oikos 120(12):1909-1920. https://doi:10.1111/j.16000706.2011.19372.x

45. Lucía DS, Cailleret M, Sterck F, Jansen S, Kramer K, Robert EMR, Aakala T, Amoroso MM, Bigler C, Camarero JJ, Čufar K, Gea-Izquierdo G, Gillner S, Haavik LJ, Hereş AM, Kane JM, Kharuk VI, Kitzberger T, Klein T, Levanič T, Linares JC, Mäkinen H, Oberhuber W, Papadopoulos A, Rohner B, Sangüesa-Barreda G, Stojanovic DB, Suárez ML, Villalba R, Martínez-Vilalta J (2020) Low Growth Resilience to Drought Is Related to Future Mortality Risk in Trees. Nature Communications 11(1):545554. https://doi:10.1038/s41467-020-14300-5

46. Lutz JA, van Wagtendonk JW, Franklin JF (2009) Twentieth-century decline of large diameter trees in Yosemite National Park, CA, USA. Forest Ecology and Management 257(11):2296-2307. https://doi:10.1016/j.foreco.2009.03.009

47. Lyu L, Suvanto S, Nöjd P, Henttonen HM, Mäkinen H, Zhang QB (2017) Tree growth and its climate signal along latitudinal and altitudinal gradients: comparison of tree rings between Finland and Tibetan Plateau. Biogeosci. Discuss 14(12):3083-3095. https://doi:10.5194/bg-14-3083-2017

48. Matusick G, Ruthorf KX, Fontaine JB, Fontaine JB, Hardy GESJT, Gilliam F (2016) Eucalyptus forest shows low structural resistance and resilience to climate change-type drought. Journal of Vegetation Science 27(3):493-503. https://doi:10.1111/jvs.12378

49. McDowell NG, Beerling DJ, Breshears DD, Fisher RA, Raffa KF, Stitt M (2011) The interdependence of mechanisms underlying climate-driven vegetation mortality. Trends in Ecology and Evolution 26(10):523-532. https://doi:10.1016/j.tree.2011.06.003

50. McDowell NG, Allen CD (2015) Darcy's law predicts widespread forest mortality under climate warming. Nature Climate Change 5(7):669-672. https://doi:10.1038/nclimate2641

51. McDowell NG, Allen CD, Anderson-Teixeira K, Aukema BH, Bond-Lamberty B, Chini L, Clark JS, Dietze M, Grossiord C, Hanbury-Brown A, Hurtt GC, Jackson RB, Johnson DJ, Kueppers L, Lichstein JW, Ogle K, Poulte B, Pugh TAM, Seidl R, Turner MG, Uriarte M, Walker AP, Xu CG (2020). Pervasive shifts in 
forest dynamics in a changing world. Science 368(6494): eaaz9463.

https://doi:10.1126/science.aaz9463

52. McGregor IR, Ryan H, Norbert K, Tepley AJ, Gonzalez-Akre EB, Herrmann V, Zailaa J, Stovall AEL, Bourg NA, William JM, Pederson N, Sack L, Anderson-Teixeira KJ (2020) Tree height and leaf drought tolerance traits shape growth responses across droughts in a temperate broadleaf forest. New Phytologist. https://doi:10.1111/nph.16996

53. Mclntyre PJ, Thorne JH, Dolanc CR, Flint AL, Flint LE, Kelly M, Ackerly DD (2015) Twentieth-century shifts in forest structure in California: Denser forests, smaller trees, and increased dominance of oaks. Proceedings of the National Academy of Sciences 112(5):1458-

1463. https://doi:10.1073/pnas.1410186112

54. Merlin M, Perot T, Perret S, Korboulewsky N, Vallet P (2015) Effects of stand composition and tree size on resistance and resilience to drought in sessile oak and Scots pine. Forest Ecology and Management 339:22-33. https://doi:10.1016/j.foreco.2014.11.032

55. Nepstad DC, Tohver IM, Ray D, Moutinho P, Cardinot G (2007) Mortality of large trees and lianas following experimental drought in an Amazon forest. Ecology 88(9):2259-2269. https://doi:10.2307/27651365

56. Panthi S, Bräuning A, Zhou ZK, Fan ZX (2018) Growth response of Abies georgei to climate increases with elevation in the central Hengduan Mountains, southwestern China. Dendrochronologia 47:1-9. https://doi:10.1016/j.dendro.2017.11.001

57. Peng CH, Ma ZH, Lei XD, Zhu Q, Chen H, Wang WF, Liu SR, Li WZ, Fang XQ, Zhou XL (2011) A drought-induced pervasive increase in tree mortality across Canada's boreal forests. Nature Climate Change 1(9):467-471. https://doi:10.1038/nclimate1293

58. Primicia I, Camarero JJ, Janda P, Čada V, Morrissey RC, Trotsiuk V, Bače R, Teodosiu M, Svoboda M (2015) Age, competition, disturbance and elevation effects on tree and stand growth response of primary Picea abies forest to climate. Forest Ecology and Management 354:77-

86. https://doi:10.1016/j.foreco.2015.06.034

59. Ren P, Rossi S, Gricar J, Liang E, Cufar K (2015) Is precipitation a trigger for the onset of xylogenesis in Juniperus przewalskii on the north-eastern Tibetan Plateau? Annals of Botany 115(4):629-639. https://doi:10.1093/aob/mcu259

60. Rossi S, Girard MJ, Morin H (2014). Lengthening of the duration of xylogenesis engenders disproportionate increases in xylem production. Global Change Biology 20(7):22612271. https://doi:10.1111/gcb.12470

61. Rowland L, da Costa ACL, Galbraith DR, Oliveira RS, Binks OJ, Oliveira AAR, Pullen AM, Doughty CE, Metcalfe DB, Vasconcelos SS, Ferreira LV, Malhi Y, Grace J, Mencuccini M, Meir P (2015). Death from drought in tropical forests is triggered by hydraulics not carbon starvation. Nature 528:119-122. https://doi:10.1038/nature15539

62. Ryan M, Binkley D, Fownes J (1997) Age-related decline in forest productivity: pattern and process. Advances in Ecological Research 27:213-262. https://doi:10.1016/s0065-2504(08)60009-4 
63. Ryan MG, Phillips N, Bond BJ (2006) The hydraulic limitation hypothesis revisited. Plant Cell and Environment 29(3):367-381. https://doi:10.1111/j.1365-3040.2005.01478.x

64. Sala A, Woodruf DR, Meinzer FC (2012) Carbon dynamics in trees: feast or famine? Tree Physiology 32(6):764-775. https://doi:10.1093/treephys/tpr143

65. Sánchez-Salguero R, Camarero JJ, Rozas V, Génova M, Olano JM, Arzac A, Gazol A, Caminero L, Tejedor E, de Luis M, Linares JC (2018) Resist, recover or both? Growth plasticity in response to drought is geographically structured and linked to intraspecific variability in Pinus pinaster. Journal of Biogeography 45(5):1126-1139. https://doi:10.1111/jbi.13202

66. Schwarz J, Skiadaresis G, Kohler M, Kunz J, Schnabel F, Vitali V, Bauhus J (2020) Quantifying Growth Responses of Trees to Drought-a Critique of Commonly Used Resilience Indices and Recommendations for Future Studies. Current Forestry Reports 6:185-200. https://doi:10.1007/s40725-020-00119-2

67. Serra-Maluquer X, Mencuccini M, Martínez-Vilalta J (2018) Changes in tree resistance, recovery and resilience across three successive extreme droughts in the northeast Iberian Peninsula. Oecologia 187(1):343-354. https://doi:10.1007/s40725-020-00119-2

68. Shen JY, Li ZS, Gao CJ, Li SF, Huang XB, Lang XD, Su JR (2020) Radial growth response of Pinus yunnanensis to rising temperature and drought stress on the Yunnan Plateau, southwestern China. Forest Ecology and Management 474:118357. https://doi:10.1016/j.foreco.2020.118357

69. Shen JY, Li SF, Huang XB, Lei ZQ, Shi XQ, Su JR (2019) Radial growth responses to climate warming and drying in Pinus yunnanensis in Nanpan River Basin. Journal of Plant Ecology 43(11):946-958. (In Chinese) https://doi:10.17521/cjpe.2019.0169

70. Sterl A, Severijns C, Dijkstra H, Hazeleger W, Jan van Oldenborgh G, van den Broeke M, Burgers G, van den Hurk B, Jan van Leeuwen Peter, van Velthoven P (2008) When can we expect extremely high surface temperatures? Geophysical Research Letters 35(14):L14703. https://doi:10.1029/2008gl034071

71. Stokes MA, Smiley TL (1996) An Introduction to Tree-Ring Dating. Arizona Uni. Press, Chicago.

72. Taeger S, Zang C, Liesebach M, Schneck V, Menzel A (2013) Impact of climate and drought events on the growth of Scots pine (Pinus sylvestrisL.) provenances. Forest Ecology and Management 307:3042. https://10.1016/j.foreco.2013.06.053

73. Trenberth KE, Dai A, Van Der Schrier G, Jones PD, Barichivich J, Briffa KR, Sheffield J (2013) Global warming and changes in drought. Nature Climate Change 4(1):17-22. https://doi:10.1038/nclimate2067

74. Trumbore S, Brando P, Hartmann H (2015) Forest health and global change. Science 349(6250): 814818. https://doi:10.1126/science.aac6759

75. Trugman AT, Detto M, Bartlett MK, Medvigy D, Anderegg WRL, Schwalm C, Schaffer B, Pacala SW, Cameron D (2018) Tree carbon allocation explains forest drought-kill and recovery patterns. Ecology Letters 21(10):1552-1560. https://doi:10.1111/ele.13136 
76. Vicente-Serrano SM, Camarero JJ, Azorın-Molina C (2014) Diverse responses of forest growth to drought time scales in the Northern Hemisphere. Global Ecology and Biogeography 23(9): 10191030. https://doi:10.1111/geb.12183

77. Wang ZY, Yang B, Deslauriers A, Bräuning A (2015b) Intra-annual stem radial increment response of Qilian juniper to temperature and precipitation along an altitudinal gradient in northwestern China. Trees 29(1):25-34. https://doi:10.1007/s00468-014-1037-7

78. Wigley TML, Briffa KR, Jones PD (1984) On the Average Value of Correlated Time Series, with Applications in Dendroclimatology and Hydrometeorology. Journal of Climate and Applied Meteorology 23(2):201-213. https://doi:10.1175/1520-0450(1984)0232.0.C0;2

79. Wu GJ, Xu GB, Chen T, Liu XH, Zhang YF, An W, Wang WZ, Fang Z, Yu SL (2013) Age-dependent treering growth responses of Schrenk spruce (Picea schrenkiana) to climate-A case study in the Tianshan Mountain, China. Dendrochronologia 31(4):318-326.

https://doi:10.1016/j.dendro.2013.01.001

80. Yang B, He M, Shishov V, Tychkov I, Vaganov E, Rossi S, Ljungqvist FC, Bräuning A, Grießinger J (2017) New perspective on spring vegetation phenology and global climate change based on Tibetan Plateau tree-ring data. Proceedings of the National Academy of Sciences 114(27):6966-6971. https://doi:10.1073/pnas.1616608114

81. Yu GR, Liu YB, Wang XC, Ma KP (2008) Age-dependent tree-ring growth responses to climate in Qilian Juniper (Sabina przewalskii Kom.). Trees-Structure and Function 22(2):197-204. https://doi:10.1007/s00468-007-0170-y

82. Zang C, Hartl-Meier C, Dittmar C, Rothe A, Menzel A (2014) Patterns of drought tolerance in major European temperate forest trees: climatic drivers and levels of variability. Global Change Biology 20(12):3767-3779. https://doi:10.1111/gcb.12637

83. Zhang YJ, Meinzer FC, Hao GY, Scholz FG, Bucci AJ, Takahashi FSC, Villalobos-Vega R, Giraldo JP, Cao KF, Hoffmann WA, Goldstein G (2009) Size-dependent mortality in a Neotropical savanna tree: the role of height-related adjustments in hydraulic architecture and carbon allocation. Plant Cell and Environment 32(10):1456-1466. https://doi:10.1111/j.1365-3040.2009.02012.x

84. Zhang JZ, Gou XH, Manzanedo RD, Zhang F, Pederson N (2018) Cambial phenology and xylogenesis of Juniperus przewalskii over a climatic gradient is influenced by both temperature and drought. Agricultural and Forest Meteorology 260-261:165-175. https://doi:10.1016/j.agrformet.2018.06.011

\section{Figures}




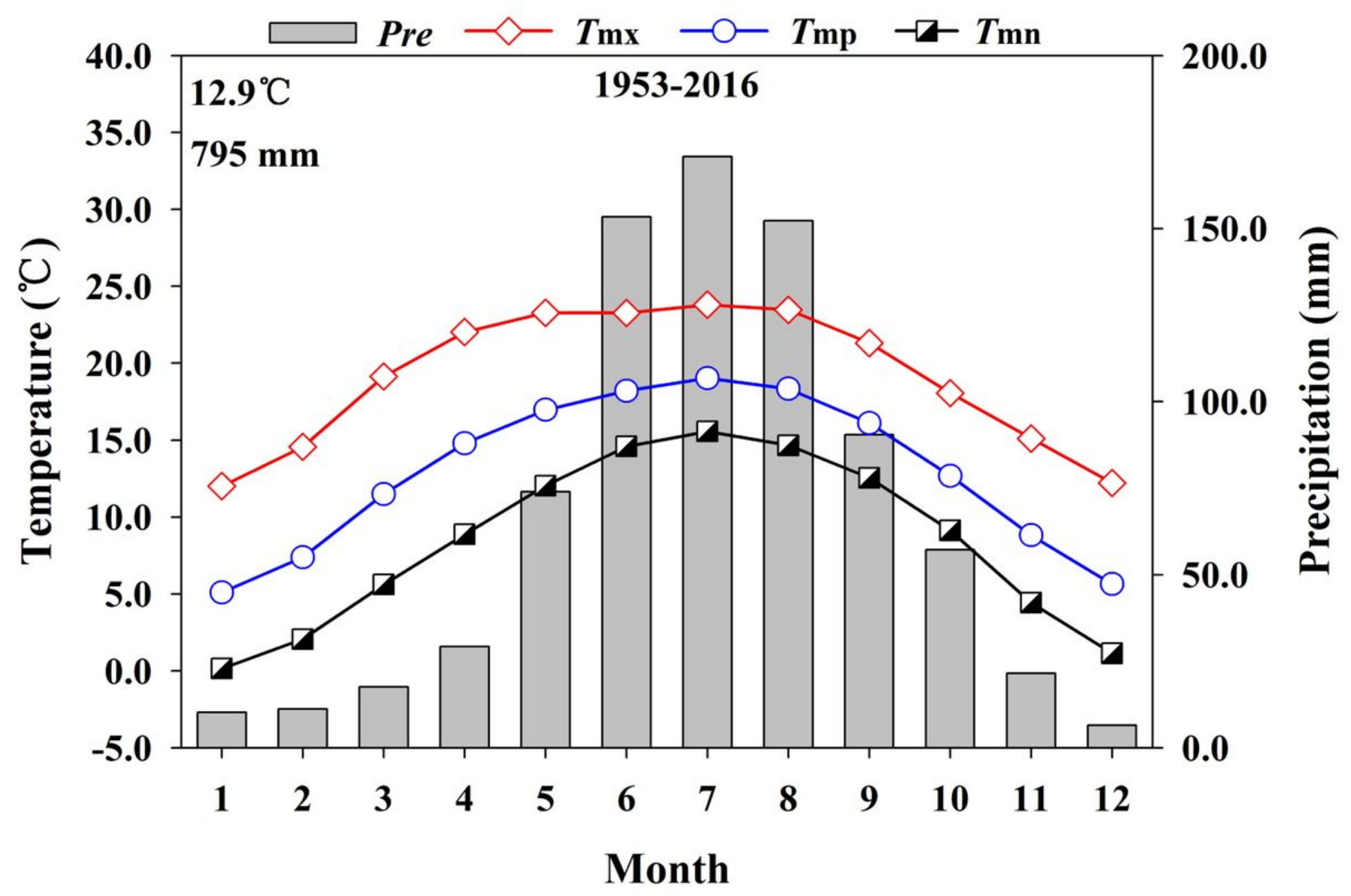

Figure 1

Climate diagrams of the study area showing monthly air temperatures and precipitation at the Huize site from 1953 to 2016. 


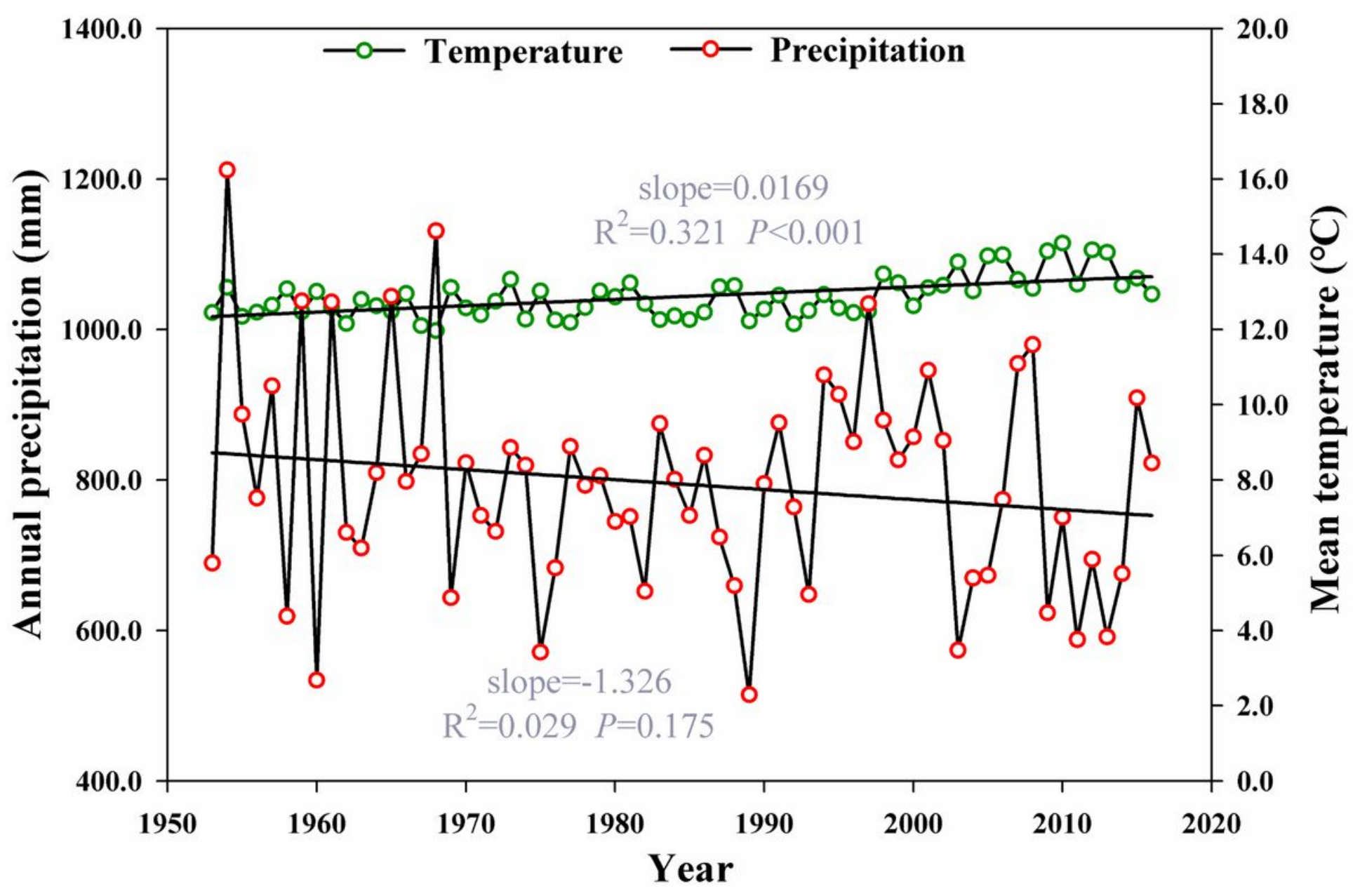

Figure 2

Annual climate trends at Huize climate station (1953-2016) 

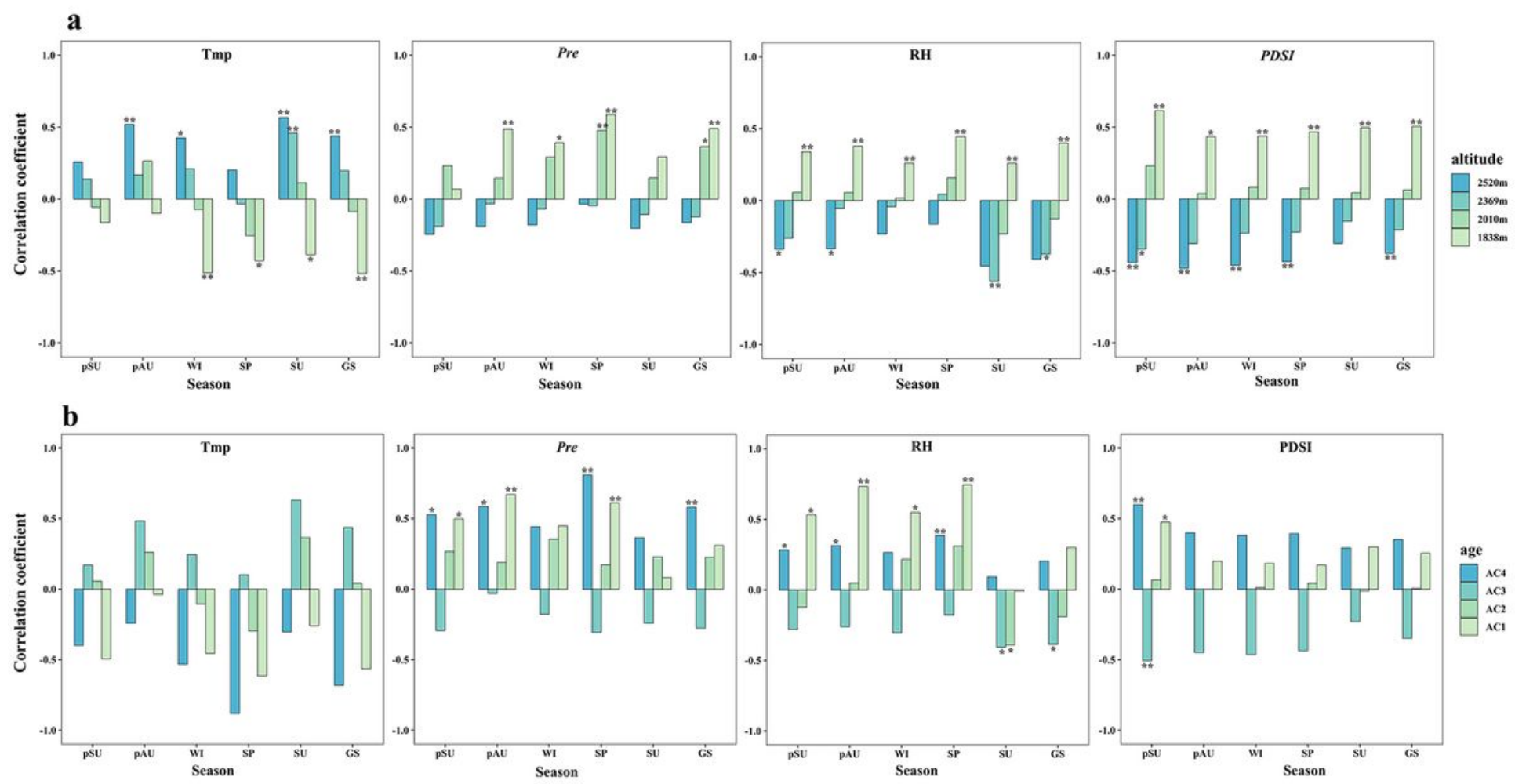

Figure 3

Correlation coefficients of standard chronologies in each age class (a) and altitude (b) with climate data of six seasons (pSU, previous summer; pAU, previous autumn; WI, winter; SP, spring; SU, summer; GS, growing season).

a

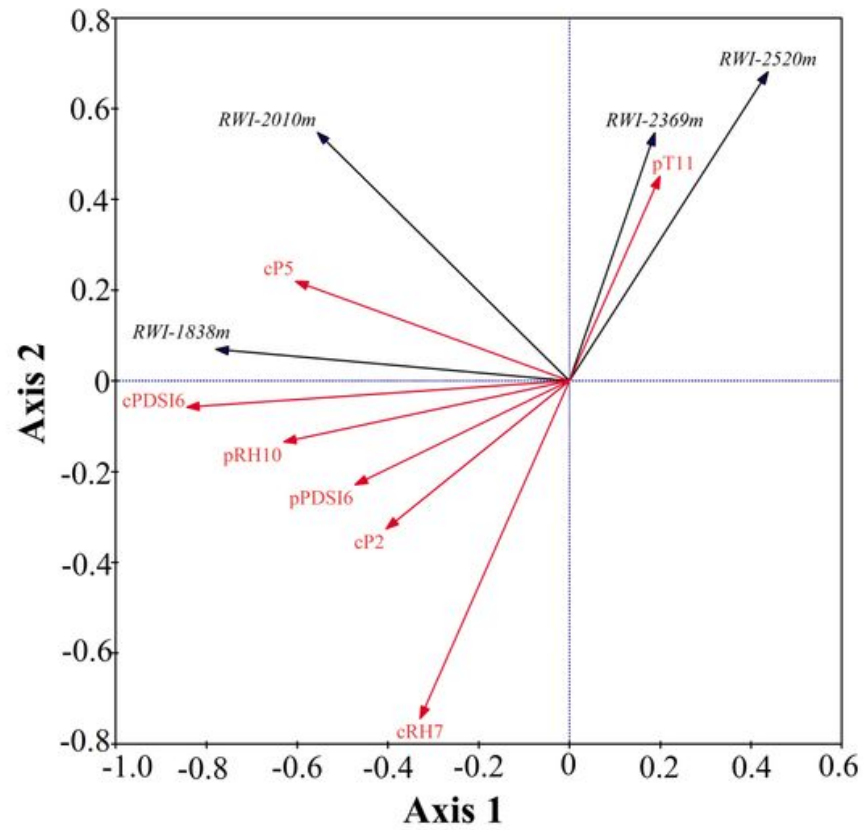

b

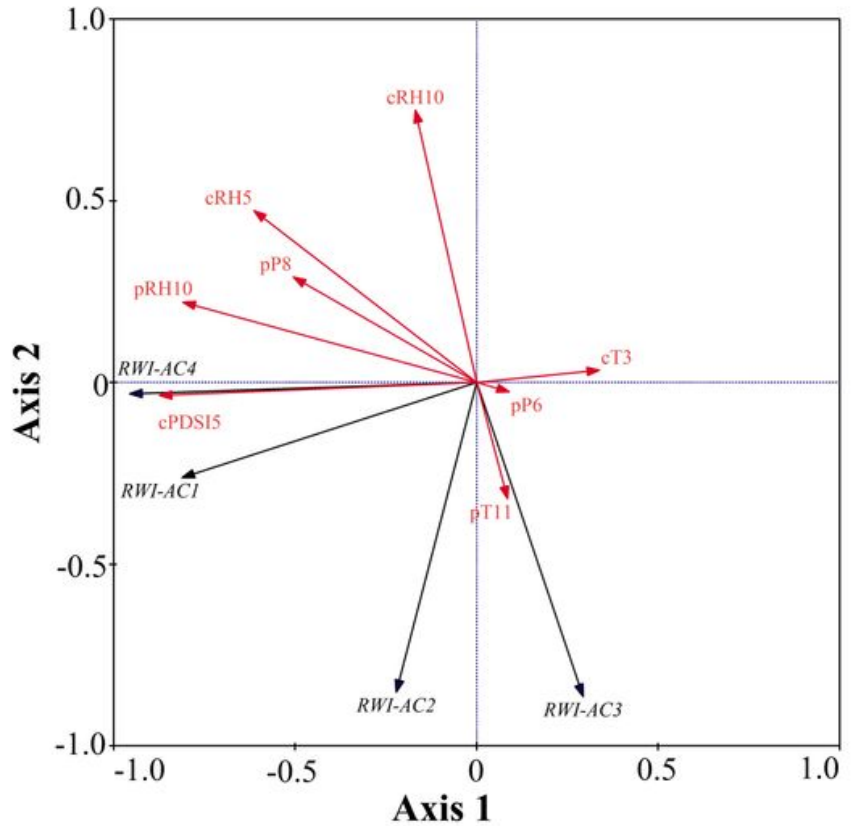

Figure 4 
Redundancy analysis between tree ring width standard chronologies and climate factors of different altitudes (a) and age classes (b) from June of the previous year to October of the current year.

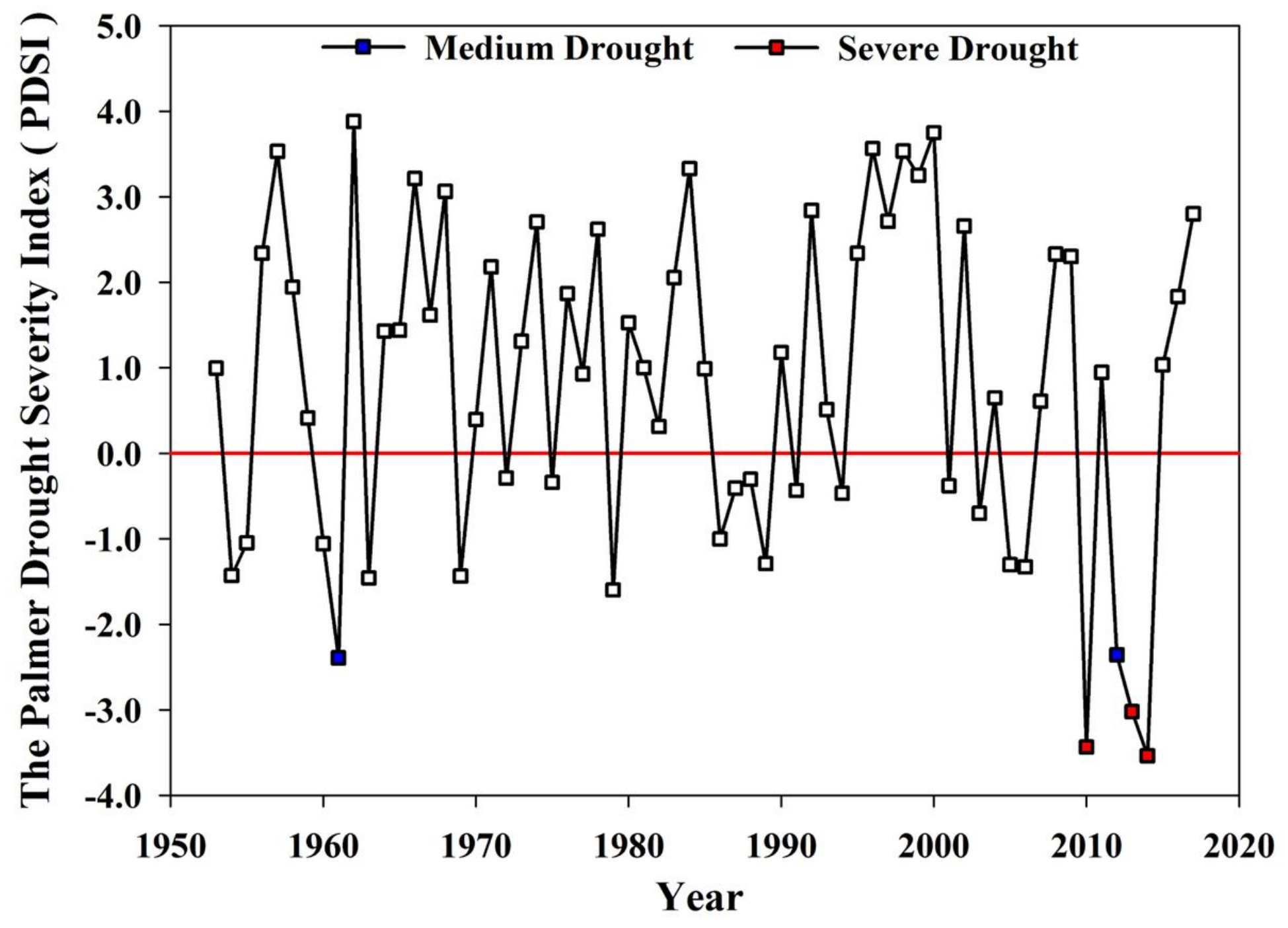

Figure 5

Identification of severe drought and medium drought years 

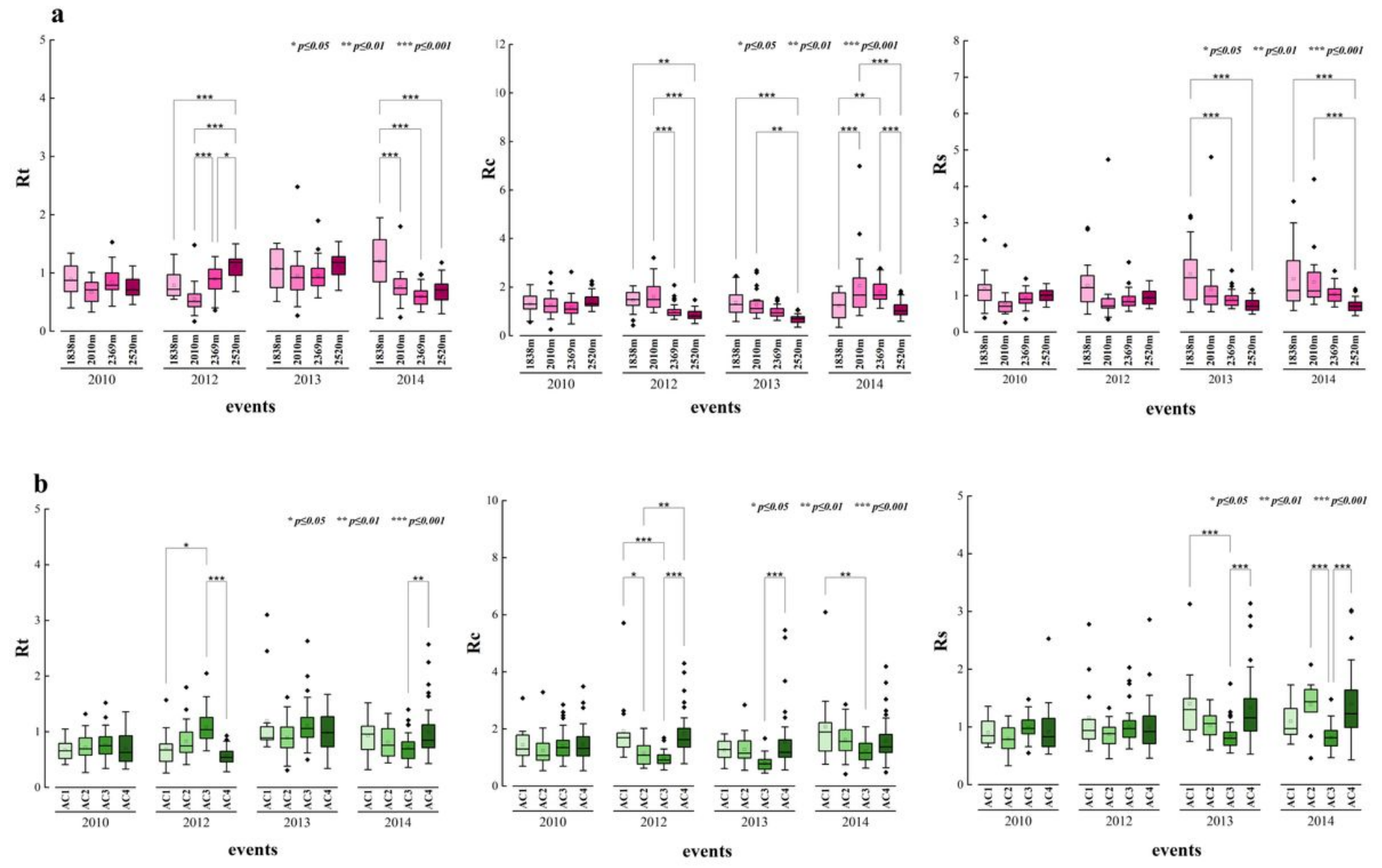

Figure 6

The resistance, recovery and resilience of each age (a) and altitude (b) to drought events
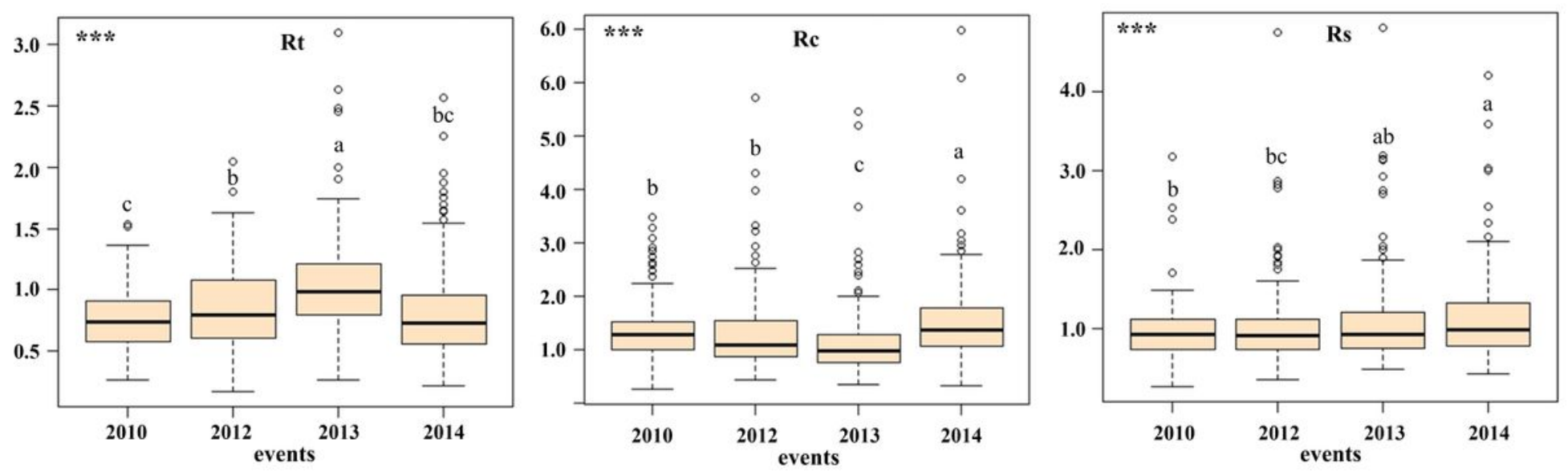

Figure 7

Temporal variation of Rt, Rc and Rs of P. yunnanensis to drought events 

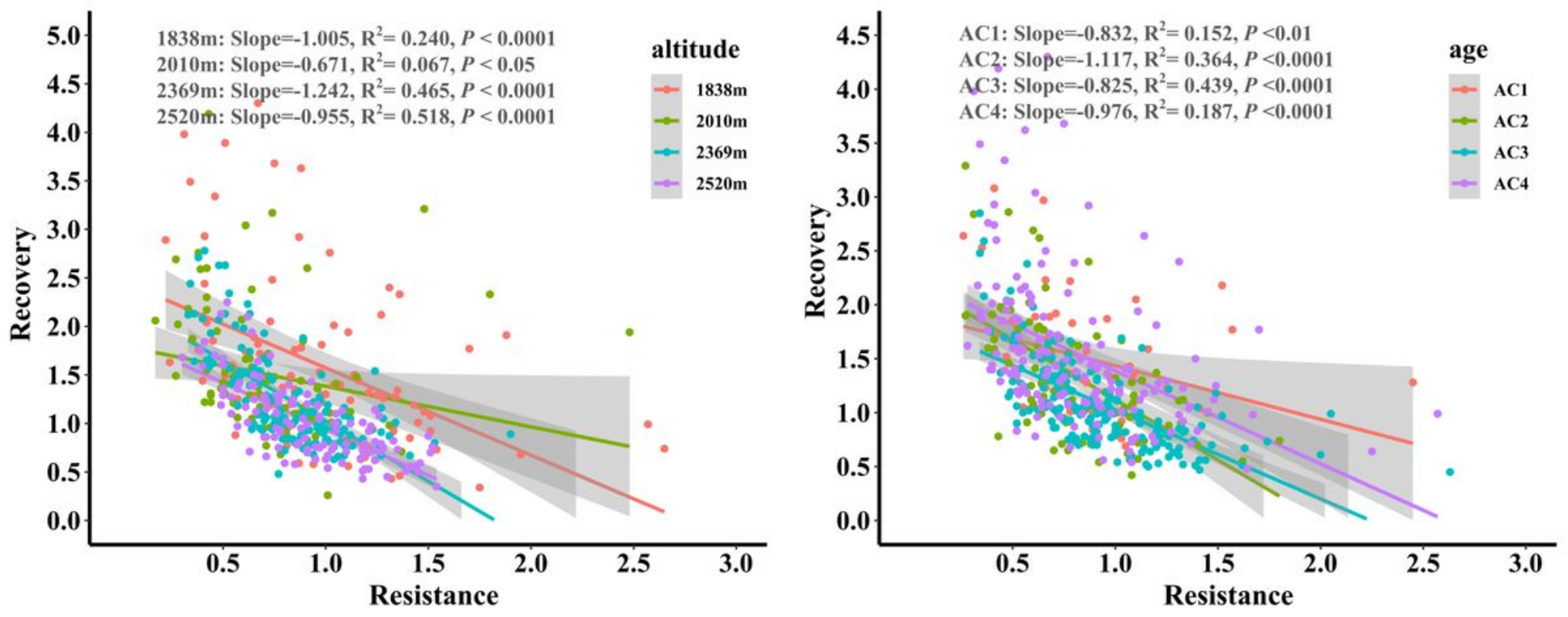

Figure 8

The relationship between recovery and resistance of trees at each altitude and age class 


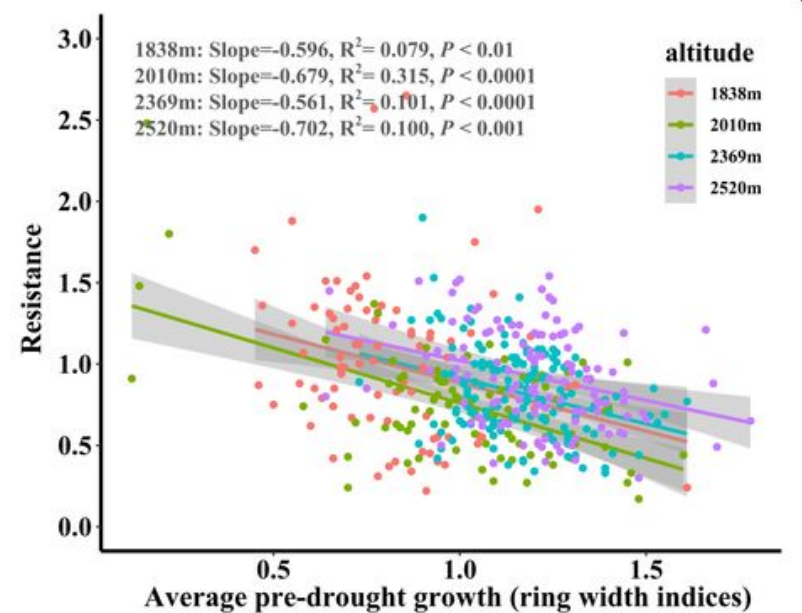

a

Average pre-drought growth (ring width indices)

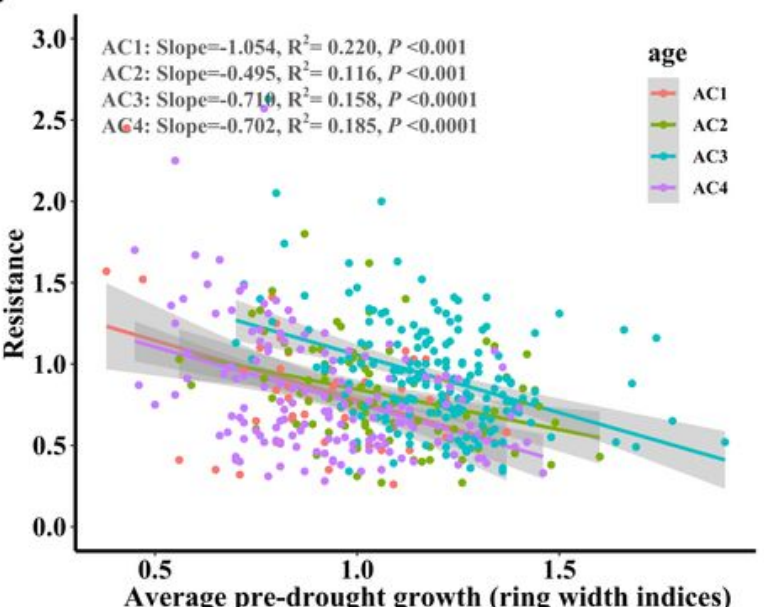

b
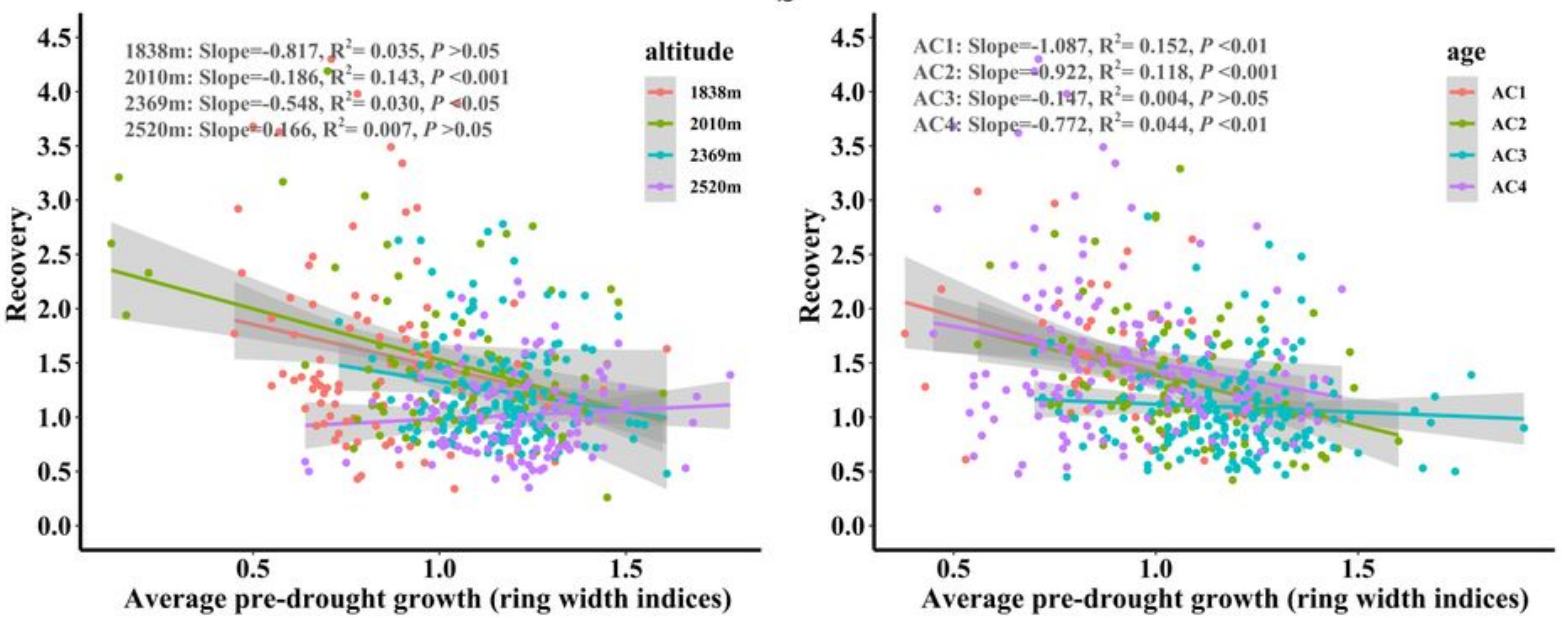

c
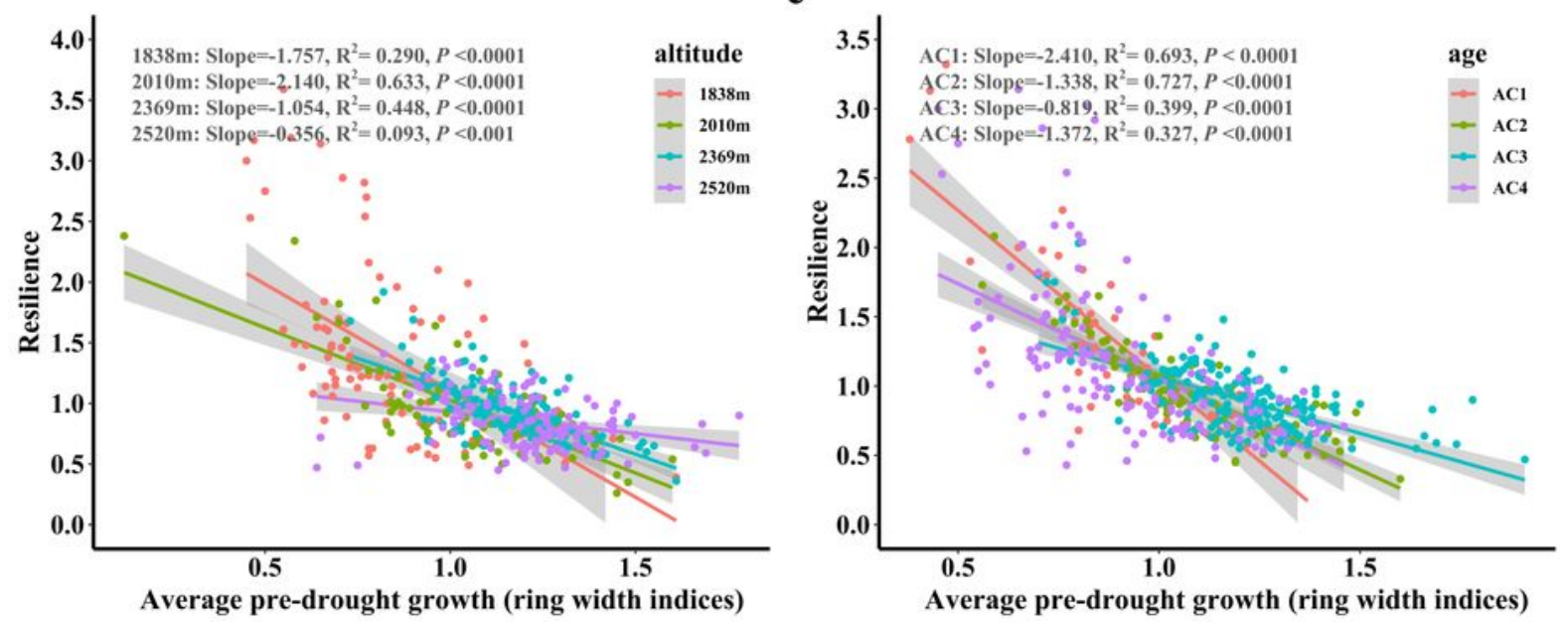

\section{Figure 9}

Tree growth resistance (a), recovery (b), and resilience (c) at different altitudes and age classes to the drought events with 95\% confidence intervals. Note: Average pre-drought growth (ring width indices) was quantified from tree growth during the 4 consecutive years prior to drought. 
This is a list of supplementary files associated with this preprint. Click to download.

- supplementaryinformations.docx 